\section{Assessment of hedge stand types as determinants of woody species richness in rural field margins}

\author{
Tommaso Sitzia $^{(1)}$, Giovanni Trentanovi ${ }^{(1)}$, Lorenzo Marini ${ }^{(2)}$, \\ Dina Cattaneo ${ }^{(1)}$, Paolo Semenzato ${ }^{(1)}$
}

The woody component along field edges often provides the only permanent elements of structural and biological diversity in landscapes that have lost much of their naturalness to agriculture and urban use. The main aims of this study were (i) to investigate how four hedge stand types, i.e., systems of management distinguished on the basis of the natural and managed growth forms of trees and shrubs (low single-storied, high single-storied, two-storied and multi-storied), differ in their biometric parameters and (ii) to identify the primary management-related determinants of native woody species richness. The study used a large dataset of hedgerows $(n=538)$ sampled in seven sites in Northern Italy. The four hedge stand types exhibited highly significant differences in size and biometric parameters. The multi-storied hedges, associated with the highest stand structural diversity index values, supported the highest number of tree species, followed by high single-storied hedges. The low singlestoried hedge stand type contained the lowest number of species. We found a positive effect of hedge area as well as a marginal negative effect of basal area on native woody species richness. The management implications addressed by our study include conversion of single-storied into two- or multi-storied types, increasing hedge size and controlling hedge stand basal area.

Keywords: Agricultural Landscape, Basal Area, Biodiversity, Hedgerow, Structure, Tree Growth Form, Management, Size

\section{Introduction}

The tree and shrub layers of rural hedges often provide the only semi-permanent element of structural and biological diversity in landscapes that have lost much of their naturalness to agriculture and urban use (Paoletti 1995, Burel 1996). These layers are composed of woody species maintained or planted by farmers routinely or in response to regulatory directives (Sutton 1992, Burel \& Baudry 1995). Hedges with a high diversity of woody species are expected to support a great abundance and diversity of associated organisms such as birds (Macdonald \& Johnson 1995, Hinsley \& Bellamy 2000 Padoa-Schioppa et al. 2006) and invertebrates (Maudsley 2000). However, woody spe-

cies richness is influenced by many factors among which hedgerow structure is of great importance (Hooper 1970, Willmot 1980, Sutton 1992, Herlin \& Fry 2000, Boutin et al. 2002, Deckers et al. 2004a, Deckers et al. 2004b, Campagne et al. 2006). Hedgerow structure has been defined in many ways, including as: (i) a combination of different biometric values (Sutton 1992, Bates \& Harris 2009); (ii) the percentage cover of the different vegetation layers (Bennett et al. 1994); (iii) a combination of these two sets of variables (Osborne 1984, Green et al. 1994, Fritz \& Merriam 1996, Herlin \& Fry 2000, Sykes \& Hannon 2001); and (iv) all of the above, combined with size and other physical measures (Deckers et al. 2004a,

(1) Department of Land, Environment, Agriculture and Forestry, University of Padova, v.le dell'Università 16, I-35020 Legnaro (PD - Italy); (2) DAFNAE-Entomology, University of Padova, v.le dell'Università 16, I-35020 Legnaro (PD - Italy)

@ Tommaso Sitzia (tommaso.sitzia@unipd.it)

Received: Aug 27, 2012 - Accepted: Mar 05, 2013

Citation: Sitzia T, Trentanovi G, Marini L, Cattaneo D, Semenzato P, 2013. Assessment of hedge stand types as determinants of woody species richness in rural field margins. iForest 6: 201-208 [online 2013-05-27] URL: http://www. sisef.it/iforest/contents/?id=ifor0749-006

Communicated by: Paola Mairota
Campagne et al. 2006, Roy \& de Blois 2008, Wehling \& Diekmann 2008). However, despite the number of structure classification schemes, little attention has been paid to the significance of stand biometric differences among the structure types, which are always recognized through visual estimation in the field and hence highly subject to error. The present paper introduces and validates, through a post-analysis of biometric differences among the groups, a criterion for classifying rural hedge stands based on the relative contribution of trees, coppice, pollards and shrubs to the hedgerow. Based on this criterion, primary management-related determinants of native woody species richness are identified. Specifically, a large dataset was used, including data from more than 500 hedges located in the Padua-Venetian intensive peri-urban agricultural landscapes. The use of this shorthand recording system of hedge stand types, which incorporates biometric values and woody species growth form categories, increases the applicability of the existing hedgerow structure classification scheme to planning and management.

\section{Materials and methods}

\section{Study area}

The Padua-Venetian plain is a sub-region of the Po Plain located in the north-eastern part of Italy and occupying an area of approximately $10372 \mathrm{~km}^{2}$ (Fig. 1). Mean annual precipitation and temperature vary between 700 and $1100 \mathrm{~mm}$ and 13 to 13.5 ${ }^{\circ} \mathrm{C}$, respectively. All the sites are nearly flat, the site with the highest elevation (Montegalda) being located at $63 \mathrm{~m}$ a.s.l. The study region is located in the north Mediterranean environmental zone (Metzger et al. 2005). The area has been subjected to substantial transformations that have modified the landscape structure, since the Roman centuriation in the $1^{\text {st }}$ century $\mathrm{BC}$ up to the industrial settlements in the 1970s (Tempesta 2010). At present, $49-85 \%$ of the region is agricultural and maize, soybean, others cereals and wine grapes are the dominant crops (Regione Veneto 2006). Hedgerows were established or modified in different periods, and spontaneous regeneration of plant species is possible where their function is not exclusively ornamental (Zanaboni \& Lorenzoni 1989, Sitzia 2007).

\section{Data collection}

Site selection criteria were conditioned according to landscape structure, which has been shaped by the aforementioned changes in land use. Seven sites (Fig. 1) were ultimately selected on the basis of differences in agricultural intensity, measured according to mean enterprise Utilized Agricultural Area (UAA) classes as recorded at the municipal 
Fig. 1 - Italy, Veneto region and location of the surveyed sites.

(1): Canda;

(2): Frassinelli;

(3): Montegalda;

(4): Nogara;

(5): Peseggia;

(6): Piove di Sacco

(7): Roncade.

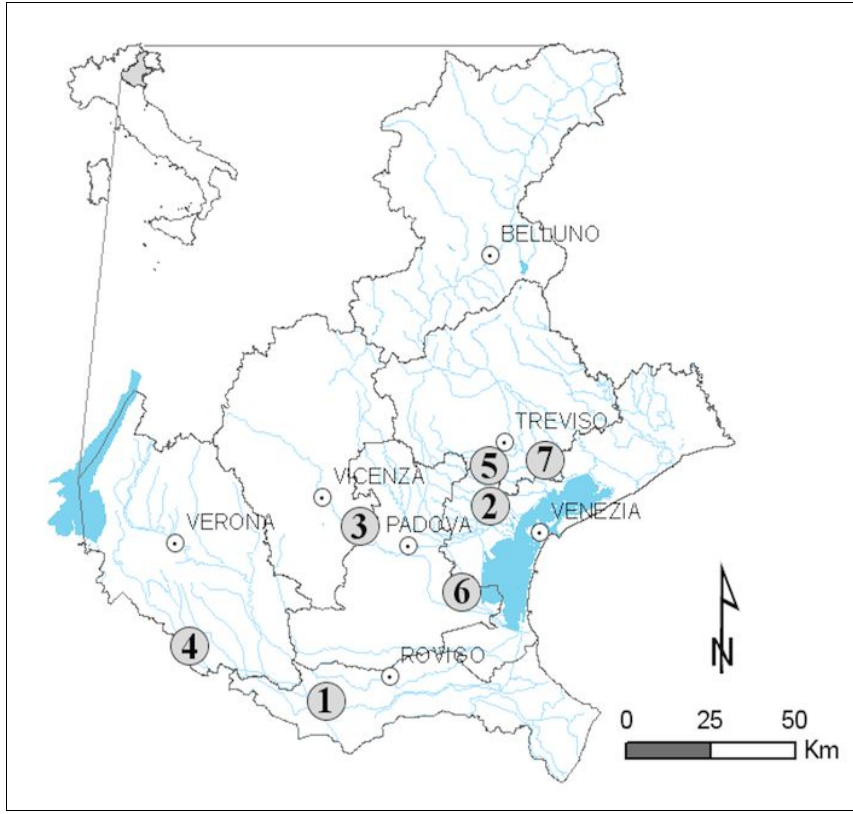

level. Data on these classes are easily achievable, and the classification system is linked to the parceling of the rural landscape, which is an important factor in determining the quality of landscape management by the enterprises (Trisorio 2005).

The UAA classes considered are (CIA 2003):

- high ( $\geq 10$ ha)

- intermediate (3-10 ha)

- low (<3 ha)

Similarly to the mean UAA, hedgerow density in each site reflects different agricultural landscape assets and land use histories, from the ancient agricultural landscape of Roman centuriation to the intensive agricul-

tural lands reclaimed in the Early and Late Medieval Ages or in more recent times (Tempesta 1989, Meeus et al. 1990, Regione Veneto 2007).

The general definition of a hedgerow is a row of woody plants, including hedge and herbaceous species, that separates adjacent fields (Pollard et al. 1974, Forman \& Baudry 1984) and is managed to some degree (Baudry et al. 2000). In this study we adopted a definition based on several sources (Bidese \& Peruffo 1993, Bickmore 2002) and define hedgerows using the following criteria (Tab. 1):

- the function is not exclusively ornamental, and spontaneous regeneration of plants is

Tab. 1 - Thresholds used to define a hedgerow.

\begin{tabular}{lcl}
\hline Measure & Threshold & Reference \\
\hline \% gap & $<35 \%$ & Bickmore (2002) \\
Gap length & $<20 \mathrm{~m}$ & Bickmore (2002) \\
Hedgerow length & $>20 \mathrm{~m}$ & Bickmore (2002) \\
Hedgerow width & $<30 \mathrm{~m}$ & Bidese \& Peruffo (1993) \\
\hline
\end{tabular}

possible;

- the proportion of area in tree and/or shrub cover gaps of $2 \mathrm{~m}$ or more must be less than $35 \%$;

- the length of an individual gap must not exceed $20 \mathrm{~m}$; beyond this threshold the gap is considered an opening dividing two different hedgerows;

- the minimum distance between hedgerows must be $20 \mathrm{~m}$;

- the width must not exceed $20 \mathrm{~m}$.

Within each site, all hedgerows fulfilling these requirements were surveyed with the aim of obtaining a total sample of 50-60 km of hedgerow in each UAA class. Therefore, we surveyed from a minimum of 47 to a maximum of 107 sampling units in each site, with a total of 538 hedgerows surveyed (Tab. 2).

Survey of some hedgerow characteristics involved treating the entire hedge as the sampling unit, while others were measured by subdividing the longitudinal length of the hedge into equal parts. The total number of equal parts was proportional to total hedgerow length (L) as follows: single part $(\mathrm{L}<$ $100 \mathrm{~m})$; two parts $(100 \mathrm{~m} \leq \mathrm{L}<300 \mathrm{~m})$; three parts $(300 \mathrm{~m} \leq \mathrm{L}<600 \mathrm{~m})$; four parts $(\mathrm{L} \geq 600 \mathrm{~m})$. In the center of each part, a sampling subunit of $10 \mathrm{~m}$ was surveyed. The values recorded in the subunits were then averaged for the entire hedgerow.

Identification of the following hedge stand types was performed through analysis of the presence of natural and managed growth forms of woodland trees and shrubs (sensu Peterken 1993, pp. 224 - trees, coppice, pollards, shrubs), which shape the hedgerows and contribute to the varying complexity in vertical structure:

- multi-storied (formed by trees, shrubs, coppices, with or without pollards);

- two-storied (formed by pollards and shrubs, pollards and coppices, trees and shrubs or trees and coppices);

- low single-storied (formed by coppices and shrubs, coppices only or shrubs only);

- high single-storied (formed by pollards and trees, pollards only, or trees only).

Tab. 2 - Surveyed sites.

\begin{tabular}{|c|c|c|c|c|c|c|}
\hline Sites & Provinces & Municipalities & $\begin{array}{c}\text { UAA } \\
\text { classes }\end{array}$ & $\begin{array}{l}\text { Site area } \\
\text { (ha) }\end{array}$ & $\begin{array}{c}\text { Sites hedgerow } \\
\text { densities }(\mathbf{k m} \\
\left.100 \mathrm{ha}^{-1}\right)\end{array}$ & $\begin{array}{l}\text { No. sampling } \\
\text { units }\end{array}$ \\
\hline Nogara & Verona & Nogara, Gazzo Veronese, Sorgà & $\mathrm{H}$ & 625 & 2.7 & 59 \\
\hline Rovigo & Rovigo & Canda, CastelGuglielmo & $\mathrm{H}$ & 4572 & 0.85 & 68 \\
\hline Piove & Padova & Piove di Sacco, Arzegrande, Brugine, Pontelongo & $\mathrm{L}$ & 420 & 6.97 & 107 \\
\hline Frassinelli & Venezia & Martellago, Spinea, Venezia & $\mathrm{L}$ & 158 & 8.67 & 47 \\
\hline Peseggia & $\begin{array}{l}\text { Treviso } \\
\text { Venezia }\end{array}$ & Zero Branco, Scorzè & $\mathrm{L}$ & 175 & 8.14 & 59 \\
\hline Roncade & Treviso & Roncade & I & 645 & 3.79 & 106 \\
\hline Montegalda & Vicenza & Grisignano di Zocco, Montegalda & I & 627 & 3.92 & 92 \\
\hline \multirow{2}{*}{\multicolumn{4}{|c|}{$\begin{array}{l}\text { Total } \\
\text { Mean }( \pm 95 \% \text { conf. int. })\end{array}$}} & 7222 & 2.24 & 538 \\
\hline & & & & $1031 \pm 1166$ & $5.00 \pm 2.19$ & $76.86 \pm 18.13$ \\
\hline
\end{tabular}


Fig. 2 - The hedge stand types characterised according to a combination of the maximum height of the growth forms (tree, pollard, coppice, shrub) and the number of stories (one, two, multi) present. (a): multi-storied, (b): high single-storied, (c): two-storied, (d): low single-storied (modified from Sitzia et al 2012)

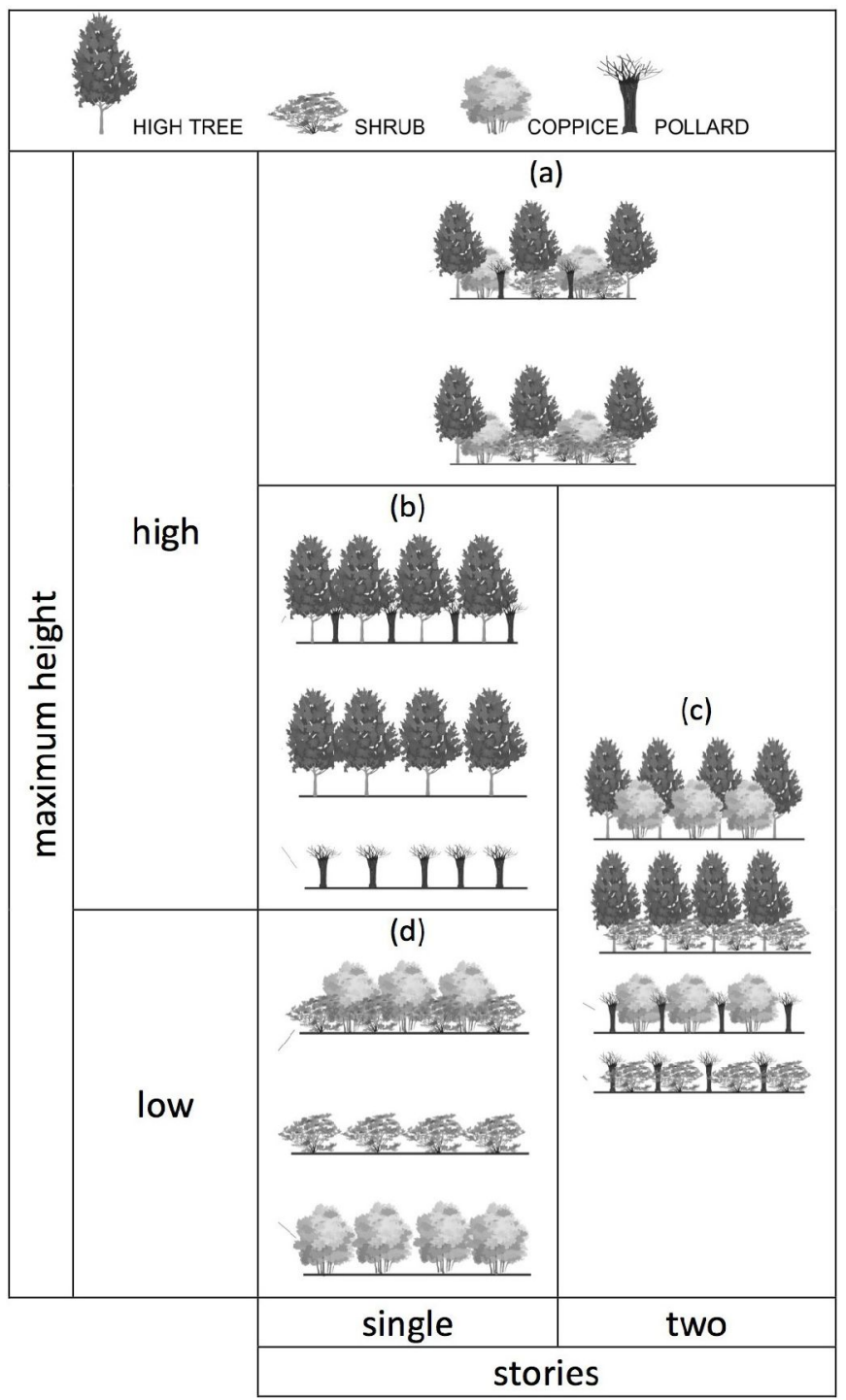

Tab. 3 - List and definition [unit of measurement] of the surveyed hedge characteristics and those of the woody plants present. $(*)$ : Sampling method indicates whether the whole hedgerow was surveyed (W) or the survey was carried out in subunits of $10 \mathrm{~m}$ hedgerow length $(\mathrm{S}) ;(* *)$ : Trees: single-stemmed individuals in the mature canopy and tall subordinate strata; coppice: trees and shrubs that have been cut and allowed to grow from the residual stump; pollards: trees cut more than one meter above ground level and allowed to grow from the residual stump.

\begin{tabular}{lcl}
\hline $\begin{array}{l}\text { Characteristic } \\
\text { Hedge stand } \\
\text { type }\end{array}$ & $\begin{array}{l}\text { Sampling } \\
\text { method* }\end{array}$ & Definition and units of measurements \\
Length & W & $\begin{array}{l}\text { Classified according to the growth forms (trees, coppice, pol- } \\
\text { lards, shrubs **) of the woody species composing the hedge } \\
\text { [multi-storied, two-storied, high single-storied, low single-sto- } \\
\text { ried]. } \\
\text { Linear development of the sampled unit (surveyed hedgerow) } \\
\text { [m]. } \\
\text { Width }\end{array}$ \\
Diameter & $\mathrm{S}$ & $\begin{array}{l}\text { Mean of the widths referring to the projection to the ground of } \\
\text { the two points of maximum expansion of the marginal crown on } \\
\text { the principal perpendicular axis of the hedge [m]. } \\
\text { Dendrometric diameter of stems with DBH } \geq 5 \mathrm{~cm} \text { in } 1 \mathrm{~cm} \\
\text { classes [cm]. } \\
\text { Height }\end{array}$ \\
$\begin{array}{l}\text { Woody species } \\
\text { richness }\end{array}$ & $\mathrm{S}$ & $\begin{array}{l}\text { Cormometric height of stems with DBH } \geq 5 \mathrm{~cm} \text { in } 1 \mathrm{~m} \text { classes } \\
\text { Number of woody species, excluding those with stems only } \\
\text { woody at the base. }\end{array}$ \\
\hline
\end{tabular}

Shrubs and coppices usually form the low storey, while pollards and trees compose the high storey (Fig. 2). The surveyed characteristics are defined in detail in Tab. 3.

We calculated the basal area from the diameters of the full range of stems $(\mathrm{DBH} \geq 5$ $\mathrm{cm})$ sampled in each hedgerow. Hedge area was equal to width $\times$ length. Two indexes of stand structural diversity were calculated: Shannon index $(\mathrm{SH})$ and Gini coefficient $(G I)$ of diameter (SHD and GID, respectively) and height ( $\mathrm{SHH}$ and $G I H$, respectively) diversity, as follows (eqn. 1):

$$
S H=-\sum_{i=1}^{n} p_{i} \ln \left(p_{i}\right)
$$

where $p_{i}$ is the number of stems of (diameter or height) size class $i$ and $n$ is the number of size classes. $S H$ values range from 0 to $\ln (n)$. $G I$ is the arithmetic average of the absolute values of the differences between all pairs of individual measurements (eqn. 2):

$$
G I=\frac{1}{2 \bar{X} n(n-1)} \sum_{i=1}^{n}(2 \mathrm{i}-n+1) X_{i}
$$

where $X_{i}$ are the sizes (diameter or height) sorted from largest to smallest $X_{1} \leq X_{2} \leq \ldots \leq$ $X_{n}$. The Gini coefficient has a minimum value of 0 when all measurements are equal and a theoretical maximum of 1.0 in an infinite population in which all measurements but one have a value of 0 : the ultimate in inequality (Latham et al. 1998). Height and diameter values are taken from the complete range of stems sampled in a single hedgerow.

Compared with other measures of stand structure diversity, the two stand structural diversity indexes described above offer many advantages, among which are their ease of calculation and wide usage, an important requisite for adoption by practitioners (Latham et al. 1998, Schulte \& Buongiorno 1998, Lexerød \& Eid 2006).

The presence and absence of woody species was determined by surveying each hedgerow and identifying every species classified as tree or shrub after Pignatti (1982). Alien species were distinguished according to Celesti-Grapow et al. (2010).

\section{Data analysis}

Differences in biometric parameters between hedge stand types were tested using a one-way ANOVA. When model residuals deviated from the normal distribution, response variables were log- or square roottransformed before analysis.

To test the effects of area, hedge stand type and basal area on the number of native woody species present, a linear mixed model was applied. The model included the variables hedge area, stand types and basal area, their interactions as fixed effects, and site as 
Tab. 4 - Mean values and standard deviations (SD) of parameters for each hedge stand type and results of the ANOVA test. (SHD): Shannon Index for tree diameters; (SHH): Shannon Index for tree heights; (GINID): Gini Index for tree diameters; (GINIH): Gini Index for tree heights; $(*): p<0.001$.

\begin{tabular}{|c|c|c|c|c|c|c|c|c|c|}
\hline \multirow{2}{*}{ Parameter } & \multicolumn{2}{|c|}{$\begin{array}{c}\text { Low single-storied } \\
(n=123)\end{array}$} & \multicolumn{2}{|c|}{$\begin{array}{l}\text { High single-storied } \\
(n=90)\end{array}$} & \multicolumn{2}{|c|}{$\begin{array}{c}\text { Two-storied } \\
(n=130)\end{array}$} & \multicolumn{2}{|c|}{$\begin{array}{c}\text { Multi-storied } \\
(n=195)\end{array}$} & \multirow[t]{2}{*}{$\mathbf{F}$} \\
\hline & Mean & SD & Mean & SD & Mean & SD & Mean & SD & \\
\hline Length (m) & 152.7 & 109.7 & 149.7 & 120.84 & 147.1 & 121.6 & 214 & 158.7 & $12.8^{*}$ \\
\hline Width (m) & 4.8 & 1.8 & 5.3 & 1.7 & 5.5 & 1.6 & 6.5 & 2.3 & $21.4^{*}$ \\
\hline Area $\left(m^{2}\right)$ & 754.9 & 697 & 795.4 & 687 & 821.8 & 737.6 & 1358.1 & 1054 & $24.2^{*}$ \\
\hline Basal area $\left(\mathrm{m}^{2} \mathrm{ha}^{-1}\right)$ & 22.7 & 31.2 & 55.5 & 89.7 & 38.8 & 49.5 & 35.5 & 31.9 & $12.2^{*}$ \\
\hline No. stems ha ${ }^{-1}$ & 4268 & 4439 & 1814 & 1638 & 2464 & 3039 & 2278 & 1861 & $19.3^{*}$ \\
\hline SHD & 1.37 & 0.6 & 1.66 & 0.58 & 1.51 & 0.63 & 1.97 & 0.56 & $31.1^{*}$ \\
\hline $\mathrm{SHH}$ & 0.99 & 0.55 & 1.03 & 0.55 & 1.19 & 0.58 & 1.49 & 0.5 & $28.3^{*}$ \\
\hline GINID & 0.09 & 0.07 & 0.08 & 0.08 & 0.12 & 0.08 & 0.13 & 0.05 & $17.6^{*}$ \\
\hline GINIH & 0.15 & 0.1 & 0.18 & 0.1 & 0.21 & 0.13 & 0.28 & 0.12 & $35.6^{*}$ \\
\hline
\end{tabular}

a random effect to account for spatial nestedness in sampling. The potential interaction between hedge area and stand type was examined to determine whether hedge stand type affects the slope of the species-area curve. The potential interaction between hedge stand type and basal area was also examined to determine whether the effect of increasing basal area on native woody species richness varies with hedge stand type. All statistical analyses were performed using the statistical package R ( $\mathrm{R}$ Development Core Team 2011). As suggested by Pinheiro $\&$ Bates (2000), a sequential F-test was used to investigate the main effects and interactions in all models using the lme function in the nlme library (Pinheiro et al. 2011) in R with the restricted maximum likelihood (REML) estimation method.

\section{Results}

Biometric parameters differed significantly between the four hedge stand types (Tab. 4). Multi-storied hedges had the highest values of area as well as of both structural diversity (Shannon and Gini) indexes. Moreover, the highest values of stem basal area $\mathrm{ha}^{-1}$ and of the number of stems ha ${ }^{-1}$ corresponded with the high single-storied and low single-storied hedge stand types, respectively.

The most common woody species (those present in $\geq 20 \%$ of sampled hedgerows) were: Salix alba L., Cornus sanguinea L., Platanus hybrida Bot., Sambucus nigra L., Rubus ulmifolius Schott, Robinia pseudoacacia L., Acer campestre L., Ulmus minor Miller, Morus alba L., Populus canadensis L., Humulus lupulus L., Hedera helix L. and Corylus avellana L. A complete list of species is reported in the Appendix 1.

Native and total woody species richness were strongly correlated $(r=0.91$, $p<0.001)$. Aliens represented more than one third of the observed woody species (44 out of 122). Alien richness was moderately
Tab. 5 - Result from the linear mixed models testing the relationship between native woody species richness and hedge stand type, area, and basal area in the seven sites. No interaction between the factors remained in the model. Site was included as a random factor.

\begin{tabular}{lccc}
\hline Parameters & df & F & P \\
\hline Log (Area) & 1,526 & 284.74 & $<0.001$ \\
Hedge stand types & 3,526 & 38.358 & $<0.001$ \\
Log (Basal area) & 1,526 & 4.518 & 0.034 \\
Hedge stand types x Log (Area) & - & - & - \\
Hedge stand types x Basal area & - & - & - \\
\hline
\end{tabular}

correlated with native richness $(r=0.41$, gion.

$p<0.001)$. Most of the aliens were neo- The results of the mixed models (Tab. 5) phytes, three of which (Robinia pseudoaca- showed a highly significant effect of hedge cia L., Parthenocissus quinquefolia (L.) area $(p<0.001)$ and stand type $(p<0.001)$ on Planchon, Ailanthus altissima (Miller) native woody species richness, as well as a Swingle) are considered by Celesti-Grapow marginal negative effect of basal area et al. (2010) to be invasive in the Veneto Re- $(p=0.034)$. Multi-storied stand types suppor-

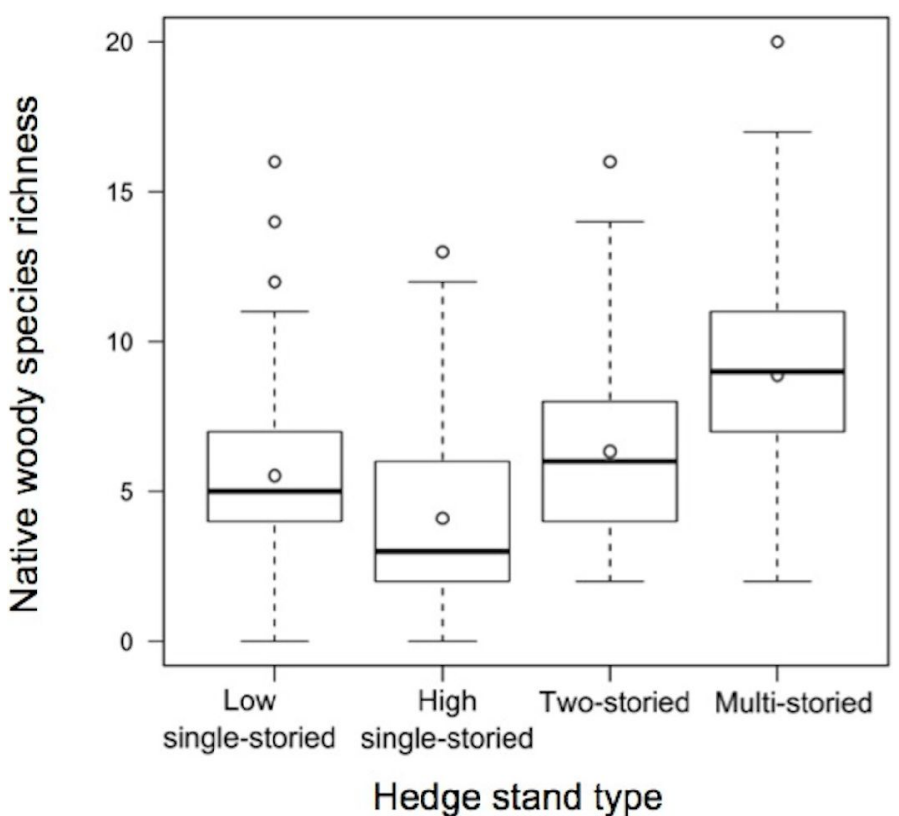

Fig. 3 - Effect of the four hedge stand types on native woody species richness. White circles within each box represent the mean, while the solid black line indicates the median. 

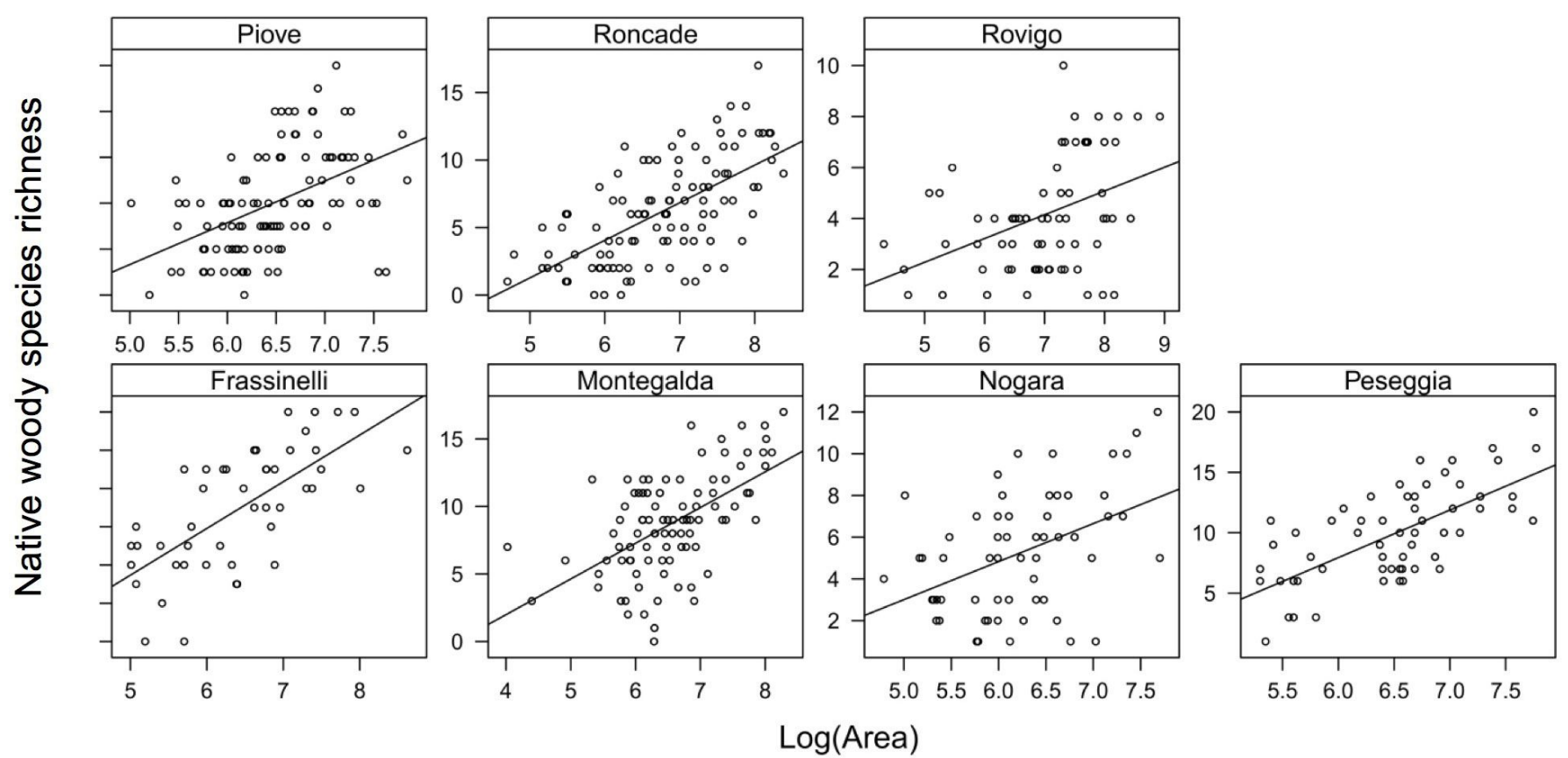

Fig. 4 - Effect of area on native woody species richness. Each plot represents one sampling site (see Tab. 1).

ted the highest number of species followed by two-storied hedgerows. High single-storied stand types contained the lowest number of species (Fig. 3). Interactions between hedge area and stand type and between basal area and stand type were not statistically significant. The slope of the relationship between hedge area and native species richness was positive (Fig. 4) and did not vary with respect to the stand type (Tab. 5).

\section{Discussion}

\section{Assessment of hedge stand types}

Each hedge stand type considered in our study exhibited a relationship with the hedgerow biometric attributes assessed. $\mathrm{Na}$ tive woody species richness was influenced by hedge stand type, area and basal area. As confirmed by the differences in the diversity indexes, basal area and tree density among the four hedge stand types, the presence of several or diverse growth forms guarantees per se higher vertical stratification. Indeed, management practices are typically characterized by cyclic cuttings along the hedgerow, whose frequency and intensity are linked to customs more than to rules, resulting in differences in both vertical tree layer development and values in structural variables. The highest values of the two stand structural diversity indexes are associated with the multi-storied system in which the presence of a multi-layered canopy is associated with a large range of stem diameters and heights and a complex horizontal arrangement of stems (McElhinny et al. 2005). Similarly, the highest basal area values were found in the high single-storied hedge stand type.

As well documented for forests (Pretzsch 1997, Brokaw \& Lent 1999), ecosystems including stands with a variety of structural components are considered likely to maintain a variety of resources and species utilizing these resources. Thus, the positive correlation between elements of biodiversity and measures of stand structural complexity observed in other ecosystems can be extended to hedgerow systems, where the more complex vertical arrangement of tree canopy found in the multi-storied hedge stand type supports a greater variety of woody species. These results are consistent with those of Franklin et al. (2002), who found that species composition and abundance can be indicators of canopy layering. Both high and low single-storied hedgerows contain fewer woody species than do hedgerows with more complex vertical structure, as reported in similar studies conducted in forest stands (e.g., Nordlind \& Ostlund 2003). Microclimatic conditions, the intensity and quality of light, resource availability and other ecological variables can explain the relationship between tree canopy structure and species richness (e.g., Parker \& Brown 2000). Our results support and extend previous findings describing the relationship between woody species richness and a variety of local hedgerow attributes (Willmot 1980, Sutton 1992, Herlin \& Fry 2000, Deckers et al. 2004a, Campagne et al. 2006) also to the spatial arrangement of tree and shrub growth forms. Most notably, the present study indicates that the identification of hedge stand types, obtained through a visual survey, may allow estimation of native woody species richness across a wide range of hedgerow network densities and landscape types, favoring interaction between decision makers, researchers and landscape users (Vos \& Meekes 1999).

Neither the effect of hedgerow area nor that of tree basal area on woody species richness was affected by hedge stand type. Species accumulation with increasing area sampled is a well know phenomenon that also applies to hedgerows (e.g., Deckers et al. 2004a). Due to the narrowness and homogeneity of hedgerows, we can hypothesize that high basal area values tend to saturate the space faster than in a wider habitat, i.e., a woodland, where the opposite trend can sometimes be observed (Risser \& Rice 1971, Liang et al. 2007).

\section{Management implications}

Management implications for native woody species richness conservation stem from the considerations discussed above. With regard to hedge stand types, the conversion of high and low single-storied hedge to two-storied or multi-storied hedgerow should be promoted. This silvicultural practice is common in forest management (Buongiorno et al. 1995, Hanewinkel 1999) but is seldom applied to hedgerow systems. As Bannister \& Watt (1995) noted, the effects of different hedge-cutting methods have been reviewed (MacLean 1992), but current information derives from anecdotes and observational studies rather than from experimental evidence. Acceptable management options may therefore include different cutting regimes for 
each hedge component, i.e., small branch cycle (3 to 10 years) for shrub species, coppicing ( 8 to 30 year cycle) for coppicing species and the tree cycle (30 to 150 years) for tall trees. Pollards can be managed with the traditional pollarding technique (see Reif \& Schmutz 2001). The pollard cycle lasts 8 to 15 years depending on species and growth rate, ensuring tree survival and allowing periodic sunlight to reach adjacent woody species. These cutting practices are intended to promote varying growth forms of one or more woody species.

Increasing hedgerow area is a recommended practice for enhancing woody species richness. Habitat availability (i.e., hedgerows, woods) at varying spatial scales has been greatly reduced where agricultural intensification has affected agricultural landscapes (Benton et al. 2003). The development of many planning tools proposing hedgerow requalification and planting (Mannino et al. 2001) arising from the Agenda 2000 framework has promoted an increase in the area occupied by existing hedgerow systems. Extending hedgerow length to connect two or more hedges is one possible solution. Another way to increase hedgerow area is to extend hedgerow width, intended as maximum canopy width. To achieve this goal, one can retain untrimmed grassy margins along the hedge, allowing spontaneous regeneration of tree species in the margins Moreover, new grassy strips of variable width could be created around all field boundaries (not just those occupied by existing hedgerows). Finally, thinning to maintain appropriate hedgerow stem density (Reif \& Schmutz 2001) can also be recommended This technique helps to avoid overly high hedgerow basal area, which can negatively influence woody species richness. The aforementioned suggestions can also be applied to enhance the total number of woody species.

\section{Conclusions and further research}

This study identified three importan hedgerow features, i.e., hedge stand type, area and basal area, that can be easily shaped by appropriate management practices to attain defined conservation targets. Based on the study results, the following practices can be recommended to enhance native woody species richness, the focus of the study: converting high single-storied and low singlestoried to multi-storied hedge stand types, increasing hedgerow length and/or width, and controlling basal area (Appendix 1).

Agro-environmental schemes should therefore support these hedgerow management practices to increase woody species richness in the rural landscape. Future work should include silvicultural studies and tests designed to identify optimal thinning and conversion techniques and their optimal spatial distribution across the landscape.
In addition, this study highlighted the frequent presence of two common alien invasive species, Robinia pseudoacacia L. and Ailanthus altissima (Miller) Swingle, suggesting their spread within hedgerows and in adjacent patches of marginal land where agricultural activities have ceased or been temporarily abandoned. Hence, future investigations should consider interactions between the management actions recommended here and the diffusion of these species. The moderate correlation between alien and native species diversity may suggest that the proposed management practices will promote growth of alien as well as native species. However, alien species distribution compared to that of native species is generally more affected by human actions (e.g., planting) thus highlighting the need to consider other explanatory variables for testing for their significance.

The presented hedge stand types embody a variety of traditional and modern management activities. This miscellany of practices indicates the flexible and adaptive character of hedgerow management to the changing landscape of the Po Plain. In the current intensive agricultural landscape, the presence of hedge features (e.g., shredded trees: trees cut at a height exceeding that of coppices but lower than pollards) linked to traditional techniques underscores the importance of cultural traditions for farmers. However, studies are needed to quantify the current significance and value that farmers and landowners confer to such hedgerows in the Po Plain. In addition, further study is needed to describe the ecosystem services that these linear landscape elements provide and the potential influence of different hedge stand types on the provisioning of such services.

\section{Acknowledgements}

We are grateful to A. Berardo (Nogara), C. Bernardi (Roncade), E. Cantarello (Frassinelli and Peseggia), L. Milan (Canda), and A. Rizzi (Montegalda and Piove di Sacco) who performed field sampling in the sites indicated in parentheses. We thank D. McCollin for his useful comments and constructive suggestions on earlier versions of this manuscript. TS and GT are also grateful to F. Viola for his valuable guidance and expertise during their academic work. The present research was partially supported with funds provided by the University of Padova (ex $60 \% 2009$ project code 60A08-4001/09 "Analisi ecologica dei sistemi arborei della pianura Padana orientale") and by the municipality of Piove di Sacco.

\section{References}

Bannister NR, Watt TA (1995). Effects of cutting on the growth of Crataegus monogyna (Hawthorn) in hedges. Journal of Environmental Management 45: 395-410. - doi: 10.1006/jema. 1995
.0084

Bates FS, Harris S (2009). Does hedgerow management on organic farms benefit small mammal populations? Agriculture, Ecosystems \& Environment 129: 124-130. - doi: 10.1016/j.agee. 2008.08.002

Baudry J, Bunce RGH, Burel F (2000). Hedgerows: an international perspective on their origin, function and management. Journal of Environmental Management 60: 7-22. - doi: 10.1006/ jema.2000.0358

Bennett AF, Henein K, Merriam G (1994). Corridor use and the elements of corridor quality chipmunks and fencerows in a farmland mosaic. Biological Conservation 68: 155-165. - doi: 10.1016/0006-3207(94)90347-6

Benton TG, Vickery JA, Wilson JD (2003). Farmland biodiversity: is habitat heterogeneity the key? Trends in Ecology and Evolution 18: 182188. - doi: 10.1016/S0169-5347(03)00011-9

Bickmore JC (2002). Hedgerow survey Handbook, a standard procedure for local surveys in the UK. Countryside Council for Wales, London, UK.

Bidese F, Peruffo A (1993). Rilievo del sistema di siepi ed alberate campestri in in'area agricola del Veneto. Acer 9 (6): 9-13. [in Italian]

Boutin C, Jobin B, Belanger L, Choiniere L (2002). Plant diversity in three types of hedgerows adjacent to cropfields. Biodiversity and Conservation 11: 1-25. - doi: 10.1023/ A:1014023326658

Brokaw NVL, Lent RA (1999). Vertical structure. In: "Maintaining biodiversity in forest ecosystems" (Hunter ML ed). Cambridge University Press, Cambridge, UK, pp. 373-399.

Buongiorno J, Peyron JL, Houllier F, Bruciamacchie M (1995). Growth and management of mixed-species, uneven-aged forests in the French Jura. Implications for economic returns and tree diversity. Forest Science 41: 397-429.

Burel F (1996). Hedgerows and their role in agricultural landscapes. Critical Reviews in Plant Sciences 15: 169-190. - doi: 10.1080/07352689. 1996.10393185

Burel F, Baudry J (1995). Social, aesthetic and ecological aspects of hedgerows in rural landscapes as a framework for greenways. Landscape and Urban Planning 33: 327-340. - doi: 10.1016/ 0169-2046(94)02026-C

Campagne P, Roche P, Tatoni T (2006). Factors explaining shrub species distribution in hedgerows of a mountain landscape. Agriculture Ecosystems \& Environment 116: 244-250. - doi: 10.1016/j.agee.2006.02.016

Celesti-Grapow L, Pretto F, Carli E, Blasi C (2010). Flora vascolare alloctona e invasiva delle regioni d'Italia. Casa Editrice Università La Sapienza, Rome, Italy.[in Italian]

CIA (2003). Atlante dell'Agricoltura Veneta. Confederazione Italiana Agricoltori, Padua, Italy. [in Italian]

Deckers B, Hermy M, Muys B (2004a). Factors affecting plant species composition of hedgerows: relative importance and hierarchy. Acta Oecologica 26: 23-37. - doi: 10.1016/j.actao. 
2004.03.002

Deckers B, Verheyen K, Hermy M, Muys B (2004b). Differential environmental response of plant functional types in hedgerow habitats. $\mathrm{Ba}$ sic and Applied Ecology 5: 551-566. - doi 10.1016/j.baae.2004.06.005

Forman RTT, Baudry J (1984). Hedgerows and hedgerow networks in landscape ecology. Environmental Management 8: 495-510. - doi: 10.1007/BF01871575

Franklin JF, Spies TA, Van Pelt R, Carey AB, Thornburgh DA, Berg DR, Lindenmayer DB, Harmon ME, Keeton WS, Shaw DC, Bible K, Chen J (2002). Disturbances and structural development of natural forest ecosystems with silvicultural implications, using Douglas-Fir forests as an example. Forest Ecology and Management 155: 399-423. - doi: 10.1016/S0378-1127(01) 00575-8

Fritz R, Merriam G (1996). Fencerow and forest edge architecture in eastern Ontario farmland. Agriculture Ecosystems \& Environment 59: 159170. - doi: 10.1016/0167-8809(96)01059-6

Green RE, Osborne PE, Sears EJ (1994). The distribution of passerine birds in hedgerows during the breeding-season in relation to characteristics of the hedgerow and adjacent farmland. Journal of Applied Ecology 31: 677-692. - doi: 10.2307/ 2404158

Hanewinkel M (1999). Successful examples of multiple forest use - the model of selection forests. In: Proceedings of the "Forests in focus: forum, biodiversity - treasures in the world's forests" (Poker J, Stein I, Werder U eds). Alfred Toepfer Akademie für Naturschutz (Hamburg, Germany) 3-7 July 1998, pp. 90-93.

Herlin ILS, Fry GLA (2000). Dispersal of woody plants in forest edges and hedgerows in a southern Swedish agricultural area: the role of site and landscape structure. Landscape Ecology 15: 229-242. - doi: 10.1023/A:1008170220639

Hinsley SA, Bellamy PE (2000). The influence of hedge structure, management and landscape context on the value of hedgerows to birds: a review. Journal of Environmental Management 60: 33 49. - doi: 10.1006/jema.2000.0360

Hooper M (1970). Dating hedges. Area 2: 63-65. [online] URL: http://www.jstor.org/stable/2000 0493

Latham PA, Zuuring HR, Coble DW (1998). A method for quantifying vertical forest structure. Forest Ecology and Management 104: 157-170. doi: 10.1016/S0378-1127(97)00254-5

Lexerød NL, Eid T (2006). An evaluation of different diameter diversity indices based on criteria related to forest management planning. Forest Ecology and Management 222: 17-28. - doi: 10.1016/j.foreco.2005.10.046

Liang J, Buongiorno J, Monserud RA, Kruger EL, Zhou M (2007). Effects of diversity of tree species and size on forest basal area growth, recruitment, and mortality. Forest Ecology and Management 243: 116-127. - doi: 10.1016/j.foreco. 2007.02.028

MacDonald DW, Johnson PJ (1995). The relationship between bird distribution and the botanical and structural characteristics of hedges. Journal of Applied Ecology 32: 492-505. - doi: 10.2307/ 2404647

MacLean M (1992). New hedges for the countryside. Farming Press Books, Ipswich, UK.

Mannino I, Franco D, Zanetto G (2001). Reti ecologiche agroforestali e processi paesaggistici: la valutazione socio-economica. Genio Rurale 1: 22-28. [in Italian].

Maudsley MJ (2000). A review of the ecology and conservation of hedgerow invertebrates in Britain. Journal of Environmental Management 60: 65-76. - doi: 10.1006/jema.2000.0362

McElhinny C, Gibbons P, Brack C, Bauhus J (2005). Forest and woodland stand structural complexity: its definition and measurement. Forest Ecology and Management 218: 1-24. doi: 10.1016/j.foreco.2005.08.034

Meeus JHA, Wijermans MP, Vroom MJ (1990). Agricultural landscapes in Europe and their transformation. Landscape and Urban Planning 18: 289-352. - doi: 10.1016/0169-2046(90)900 $16-\mathrm{U}$

Metzger MJ, Bunce RGH, Jongman RHG, Mücher CA, Watkins JW (2005). A climatic stratification of the environment of Europe. Global Ecology and Biogeography 14: 549-563. - doi: 10.1111/j.1466-822X.2005.00190.x

Nordlind E, Ostlund L (2003). Retrospective comparative analysis as a tool for ecological restoration: a case study in a Swedish boreal forest. Forestry 76: 243-251. - doi: 10.1093/forestry/ 76.2 .243

Osborne P (1984). Bird numbers and habitat characteristics in farmland hedgerows. Journal of Applied Ecology 21: 63-82. - doi: 10.2307/ 2403037

Padoa-Schioppa E, Baietto M, Massa R, Bottoni L (2006). Bird communities as bioindicators: the focal species concept in agricultural landscapes. Ecological Indicators 6: 83-93. - doi: 10.1016/j. ecolind.2005.08.006

Paoletti MG (1995). Biodiversity, traditional landscapes and agroecosystem management. Landscape and Urban Planning 31: 117-128. - doi: 10.1016/0169-2046(94)01040-F

Parker GG, Brown MJ (2000). Forest canopy stratification - is it useful? American Naturalist 155: 473-484. - doi: 10.1086/303340

Peterken G (1993). Woodland conservation and management. Second edition. Chapman \& Hall, London, UK.

Pignatti S (1982). Flora d'Italia. Edagricole, Bologna, Italy. [in Italian]

Pinheiro J, Bates D, DebRoy S, Sarkar D, R Development Core Team (2011). Linear and nonlinear mixed effects models. $\mathrm{R}$ package version 3.1-101.

Pinheiro JC, Bates DM (2000). Mixed-effects models in S and S-PLUS. Springer Verlag, New York, USA. - doi: 10.1007/978-1-4419-0318-1

Pollard E, Hooper MD, Moore NW (1974). Hedges. W. Collins Sons, London, UK.

Pretzsch H (1997). Analysis and modelling of spatial stand structures. Methodological considerations based on mixed beech-larch stands in
Lower Saxony. Forest Ecology and Management 97: 237-253. - doi: 10.1016/S0378-1127(97) 00069-8

R Development Core Team (2011). R: a programming environment for data analysis and graphics. R Development Core Team, Wien, Austria.

Regione Veneto (2006). Rapporto statistico del Veneto. Regione Veneto, Direzione sistema statistico regionale, Venice, Italy. [in Italian]

Regione Veneto (2007). Piano Territoriale Regionale di Coordinamento. Ambiti di paesaggio. Atlante ricognitivo. Regione Veneto, Venice, Italy. [in Italian]

Reif A, Schmutz T (2001). Planting and maintaining hedges in Europe. IDF, Paris, France.

Risser G, Rice EL (1971). Diversity in tree species in Oklahoma upland forests. Ecology 52: 876880. - doi: 10.2307/1936036

Roy V, de Blois S (2008). Evaluating hedgerow corridors for the conservation of native forest herb diversity. Biological Conservation 141: 298-307. - doi: 10.1016/j.biocon.2007.10.003

Schulte BJ, Buongiorno J (1998). Effects of uneven-aged silviculture on the stand structure, species composition, and economic returns of loblolly pine stands. Forest Ecology and Management 111: 83-101. - doi: 10.1016/S0378-1127 (98)00312-0

Sykes AK, Hannon SJ (2001). Fencerows as habitat for birds in an agricultural landscape in central Alberta, Canada. Ecoscience 8: 441-449.

Sitzia T (2007). Hedgerows as corridors for woodland plants: a test on the Po Plain, northern Italy. Plant Ecology 188: 235-252. - doi: 10.1007/s112 58-006-9159-7

Sitzia T, Campagnaro T, McCollin D, Dainese M (2012). A miscellany of traditional management techniques of woody field margins on the Po Plain, Italy: implications for biodiversity conservation. In: "Hedgerow Futures" (Dover JW ed). Hedgelink, Stoke-on-Trent, UK, pp. 135-146.

Sutton RK (1992). Landscape ecology of hedgerows and fencerows in Panama Township, Lancaster County, Nebraska. Great Plains Research 2: 223-254. [online] URL: http://digitalcommons.unl.edu/cgi/viewcontent.cgi article $=1072 \&$ context=greatplainsresearch

Tempesta T (1989). Introduzione allo studio del paesaggio agrario del Veneto. Veneto Agricoltura 5 (suppl.): 1-31. [in Italian].

Tempesta $\mathrm{T}$ (2010). The perception of agrarian historical landscapes: a study of the Veneto plain in Italy. Landscape and Urban Planning 97: 258272. - doi: 10.1016/j.landurbplan.2010.06.010

Trisorio A (2005). Misurare la sostenibilità, indicatori per l'agricoltura italiana. Istituto Nazionale di Economia Agraria, Rome, Italy. [in Italian]

Vos W, Meekes H (1999). Trends in European cultural landscape development: perspectives for a sustainable future. Landscape and Urban Planning 46: 3-14. - doi: 10.1016/S0169-2046(99) 00043-2

Wehling S, Diekmann M (2008). Factors influencing the spatial distribution of forest plant spe- 
cies in hedgerows of north-western Germany. Biodiversity and Conservation 17: 2799-2813. doi: 10.1007/s10531-007-9294-z

Willmot A (1980). The woody species of hedges with special reference to age in Church Broughton Parish, Derbyshire. Journal of Ecology 68 :
269-285. - doi: 10.2307/2259255

Zanaboni A, Lorenzoni GG (1989). The importance of relict vegetation and hedges in the agroecosystems and environment reconstruction. Agriculture Ecosystems \& Environment 27: 155 161. - doi: 10.1016/0167-8809(89)90081-9

\section{Supplementary Material}

Appendix 1 - List of the surveyed woody species and their frequencies.

Link: Sitzia_749@supp1001.pdf 